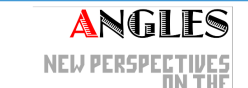

ANELOPHONE WORLD

\section{Angles}

New Perspectives on the Anglophone World

$4 \mid 2017$

Unstable States, Mutable Conditions

\title{
Mutable Conditions, Immutable Governance: Instability in U.S. Democracy
}

Zach Bastick

\section{(2) OpenEdition}

1 Journals

Electronic version

URL: https://journals.openedition.org/angles/1468

DOI: 10.4000/angles. 1468

ISSN: 2274-2042

\section{Publisher}

Société des Anglicistes de l'Enseignement Supérieur

\section{Electronic reference}

Zach Bastick, "Mutable Conditions, Immutable Governance: Instability in U.S. Democracy", Angles [Online], 4 | 2017, Online since 01 April 2017, connection on 06 June 2022. URL: http:// journals.openedition.org/angles/1468 ; DOI: https://doi.org/10.4000/angles. 1468

This text was automatically generated on 6 June 2022

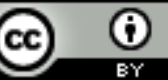

Angles est mise à disposition selon les termes de la Licence Creative Commons Attribution 4.0 International. 


\title{
Mutable Conditions, Immutable Governance: Instability in U.S. Democracy
}

\author{
Zach Bastick
}

\section{Introduction}

1 The concept of 'democracy' underpins the study of the American historical experience. It can be said to inhabit an American ideology, to structure its society, and to fuel its future. Yet an apparent 'crisis of democracy' in the United States continues to be noted in the academic literature (Foa \& Mounk; Hudson; Lessig 2012, 2015; Skocpol), evidenced through low voter turnout, citizen apathy, and a generalized dissatisfaction with democracy and its institutions. This juxtaposition raises two questions which have strong implications for the study of democracy in the United States. The first is whether the popular will of American citizens does indeed shape the political outcomes of the United States, as it is conventionally expected to do so by mainstream American political scientists (and particularly pluralists), by French civilisationistes, and by observers-analysts of the machinery and institutions of American democracy. The second question that can be raised is whether democracy, as a political model, should be expected to operate in a way that promotes the ideals that underpin it. The former question is largely empirically oriented, while the latter is largely normatively oriented. This article will seek to bridge these two orientations, in order to elucidate the core inadequacies of democracy in the United States and, from there, propose a path through which to resolve them. In doing so, it will propose a (normatively) structural approach to democracy that is (empirically) practically-informed. Future research can adopt or further this approach so as to analyse modern democratic systems, such as that of the United States, in line with democratic theory.

2 In order to explore democracy in the United States through a structural approach, this paper will effect a transition from an empirical to a normative orientation. It will first 
highlight the juxtaposition between, on the one hand, the conventional expectations of democracy and, on the other hand, the practical outcomes of democracy in the United States. More specifically, it will explore the recent evidence of a diminished engagement on the part of citizens with the political system of the United States and the prevalence of negative attitudes towards the federal government. The paper will then go on to frame this juxtaposition, drawing on elite theory and class theory and focusing in particular on the fundamental concepts of power dynamics and representation. In this way, it seeks to avoid concentrating the analysis on a series of derivative issues or symptoms, which might be more fully explained by examining the causes of those issues. In other words, the article seeks to explore certain core political problems, rather than the mere symptoms of these problems. Finally, the paper will argue that the internal power dynamics in modern democracy may tend towards the supremacy of politicians over citizens. Through this theoretically-informed framing of democracy in the United States, the paper explores the question of whether modernday democracy can survive its current structure by paving the way for a series of alternative and more fundamentally representative procedures for democracy.

\section{Empirical faltering of democracy in the United States}

Democracy is a system of popular rule. This axiom assumes that there exists in a democracy a relationship between policy and public opinion. Public support of policy, though not a sufficient condition of democracy, is a necessary one: in so far as the people do not support political outcomes in a society, that society cannot be said to be ruled by the people. This statement can then be further qualified, either systemically in order to assess the degree to which a system is democratic: are the institutions of a particular government sufficient to merit the classification as a democracy? - or analytically, to assess the health of a democracy - to what extent does an unpopular government or unsupported policy indicate an unhealthy democracy? The large body of literature on public opinion, civic empowerment, democratic accountability, and political legitimacy more generally (Dahl 1998; Habermas; Rawls; Young), gains significance due to this relationship between the state and the people in democracy.

The state of democracy in the United States frequently raises concern. Studies on democratic responsiveness have shown that policy outcomes are largely unrelated to public opinion (Barabas 2016). While public support for policy has been studied, these studies are often limited either by their convenience sampling or by the inadequately grounded breadth of their analysis. Indeed, every policy issue does not have sufficient public data, leading either to studies that depend on samples which favour high-profile issues (which tend to attract polling and are ones to which governments tend to be more responsive), or to samples that are numerically limited and from which it is difficult to generalize, due to the unclear representativeness of the samples (it would be overly costly to assess public support for every policy outcome). As a consequence, it is hard to gauge whether public opinion is sufficiently considered by government. In order to briefly shed light on the health of democracy in the United States, it is hence useful to consider more general measures, such as participation and satisfaction.

5 Turnout rate at elections is a commonly-cited indicator of a state of democracy, because elections play a central role in democratic legitimacy and because free and fair elections are sometimes considered a constituent part of the definition of modern 
democracy (Dahl 1972). Turnout rates for U.S. presidential elections have historically fluctuated, due in part to shifting cultural contexts and voting procedures. Voter turnout declined dramatically during the first two decades of the $20^{\text {th }}$ century (Kornbluh). Turnout rates for subsequent presidential elections would indeed never reach the highs of the 1880s, while the 1960 election between John F. Kennedy and Richard Nixon retained a higher turnout rate than any presidential election that followed (Figure 1). It is perhaps unintuitive that this is also true for local elections, such as for the position of mayor, because local elections concern positions that are more immediate channels of representation, and through which citizens can have a larger impact as individuals. Although disengagement from conventional channels of representation can certainly be delineated across various factors - generationally, for example, young American adults have been shown to be less likely to vote and participate in politics beyond voting than older American adults (Delli Carpini 342) the general extent of this disengagement is visible beyond the figures for voting in elections. For instance, by one estimate, only $15 \%$ of Americans have ever written to their senators, and two-thirds of mail to Congress is written by only $3 \%$ of the U.S. population (Wood 225). Due to the significance of participation to democracy, the prevalence of a generalised low engagement is an indicator which would appear to challenge the very notion that the United States is a functional or at least healthy democracy.

Figure 1: Voter turnout for president and representative elections in the United States, 1932-2010

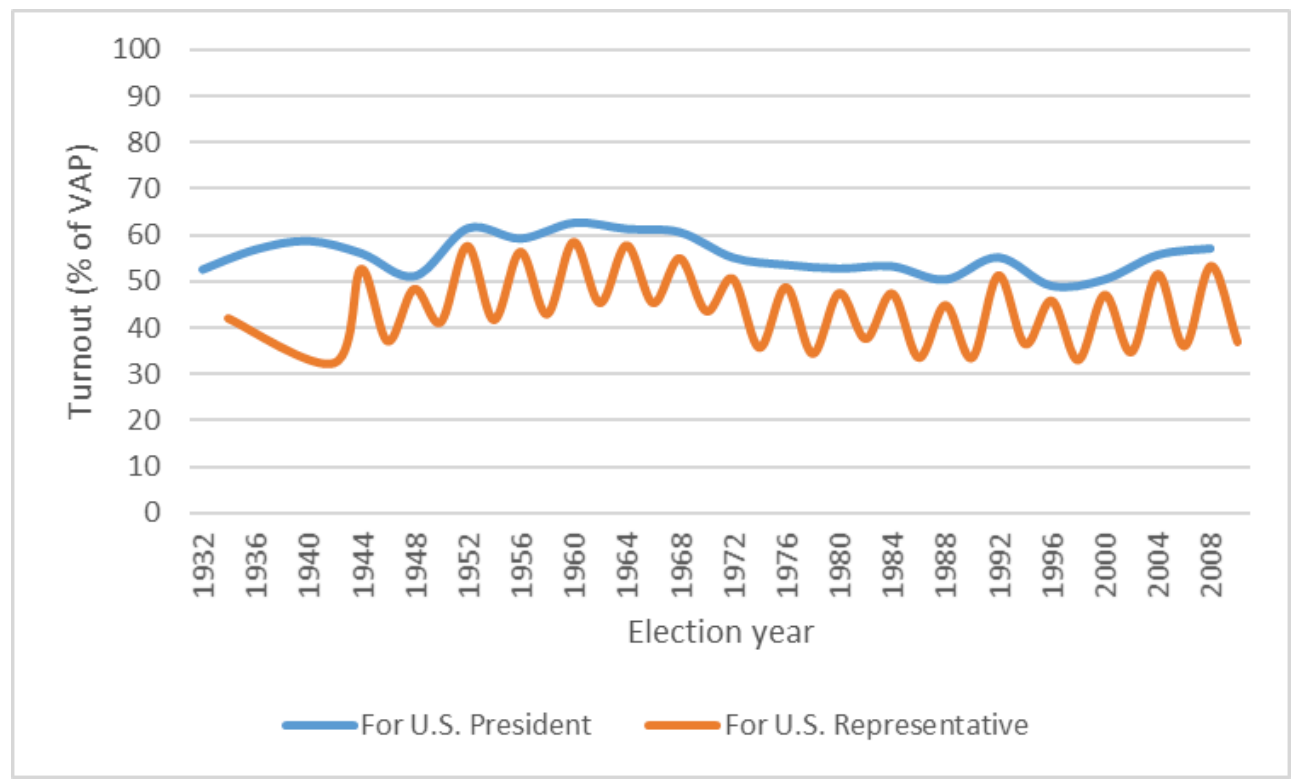

The data used to create this graph is adapted from the Huffington Post's (2013) poll database on congressional approval. This data originates from 465 polls from various pollsters including Gallup, Fox, and YouGov/Economist. This graph is created by curve-fitting (moving averages) approval and disapproval ratings from the 465 polls in the database at the time it was accessed. It should be noted that polls surveyed different populations (adults, likely voters, registered voters) using different survey methods (e.g. phone and internet). Additionally, it should be noted that I plotted the poll release dates along the primary axis rather than the polling period of the polls.

6 Low political engagement might evidence a faltering relation between the citizen and the state. Low engagement is more generally associated with a growing apathy of citizens - in part what Donald Wood calls the "emergence of the dysfunctional citizenry" (221). Wood claims that citizens no longer understand their political 
environment, are overly reliant on simplified information sources (such as television shows and stand-up comedy), and are largely less engaged in politics. This premise has been supported by Michael Delli Carpini (1996) who surveyed the range of factual information that citizens know about politics over time. Elsewhere, Delli Carpini (2000) noted a decline not only in political knowledge and the likelihood of obtaining it, but also in general civic engagement: young American adults are 'less trusting of their fellow citizens', 'less interested in politics or public affairs', 'less likely to feel a sense of identity, pride, or obligation associated with American citizenship', 'less likely to participate in community organisations designed to address public problems through collective action or the formal policy process', and 'less likely to connect individual efforts to help solve problems with more traditional, collective forms of civic engagement' (Delli Carpini 2000: 341-3).

7 Moreover, U.S. citizens have been shown to be increasingly dissatisfied with democracy and the way that democracy works in the United States. An abundant literature shows that citizens tend less and less to trust the government and tries to explain this distrust (Brooks \& Cheng; Citrin; Miller). PEW reported in January 2013 that "trust in the federal government remains mired near a historic low" (Center for the People and the Press 2013). Antagonism is strongest towards the legislative branch, followed by the executive and judicial branches, respectively (Gallup 2012). PEW found that the approval rating of Congress fell from 67\% in 1985 to $23 \%$ in 2013 (see also figure 2, which provides additional data points to this finding). Some surveys have found that, in the United States, attitudes towards government evidence a sentiment of political alienation, and sometimes animosity, on the part of citizens. Surveys have consistently evidenced a decrease in contentment with government, and an increase in anger towards government. For example, a 2015 survey found that only $18 \%$ of Americans are content with the federal government and, while $57 \%$ of Americans were frustrated with the government, $22 \%$ of Americans were angry with the government (Pew Research Center 2015: 9). Another survey found that $27 \%$ of registered voters view the government as their 'enemy' (Ibid. 34). 
Figure 2: United States Congress approval rating 2008-2013

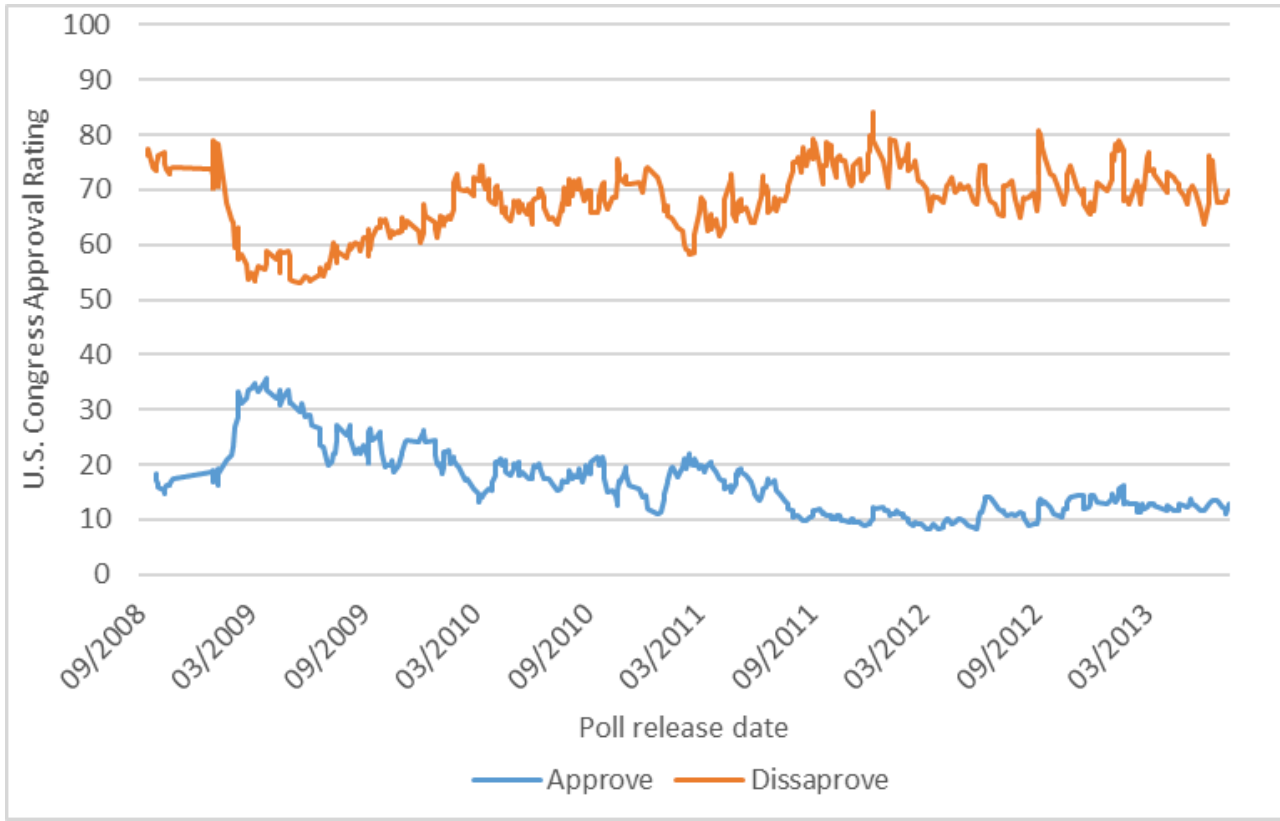

The data used to create this graph is adapted from the Huffington Post's (2013) poll database on congressional approval. This data originates from 465 polls from various pollsters including Gallup, Fox, and YouGov/Economist. This graph is created by curve-fitting (moving averages) approval and disapproval ratings from the 465 polls in the database at the time it was accessed. It should be noted that polls surveyed different populations (adults, likely voters, registered voters) using different survey methods (e.g. phone and internet). Additionally, it should be noted that I plotted the poll release dates along the primary axis rather than the polling period of the polls.

Competing hypotheses have been presented as to what this low engagement and satisfaction implies. Brooks and Cheng (2001) note that while some scholars argue that lessening trust implies dissatisfaction with the U.S. political system generally (Miller), others argue that it only implies a recurrent dissatisfaction with incumbents (e.g. Citrin). Both perspectives are significant for the long-term stability and current legitimacy of democracy. Indeed, if the former hypothesis is subscribed to, declining trust implies that representative democracies may not be sustainable as a legitimate political system. If the latter hypothesis were to be adopted, then it would imply that trust might be renewed with the accession of new office holders, but it would also however suggest that representation through the procedure of periodic, fixed-term elections gives rise to periods of lessened public control, or indeed to the removal of popular control over government - something that Rousseau (1762) also criticised in The Social Contract.

\section{Power dynamics in elite theory and class theory}

The democratic system of the United States, like those of other modern democratic nation-states, implements some degree of representative democracy (the Swiss Confederation is sometimes referred to as a direct democracy due to its strong participatory elements, but its underlying processes remain indirect). Under this system, while the people are normatively assumed to assert control over their political representatives, the role of the people in public policy is considerably diminished in comparison to its role in a direct democracy. Indeed, while in a direct democracy the 
people deliberate or vote on every issue, in a representative democracy the people place trust in politicians, to whom they delegate authority. As such, the process of representation is complicated by the introduction of elements such as politicians, parties, and platforms, and by processes such as elections. It might consequently be assumed that dissatisfaction with government and alienation from formal political processes are mediated by these additional elements. It is thus a requirement for any analysis of modern-day political behaviour and attitudes that it should explore the theoretical underpinnings of these component elements. Here, the focus of this paper is on what is perhaps the most fundamental of these components, from which the others effectively derive: the distinction between the citizen and the politician.

By delegating powers to certain individuals, representative democracy creates a political class that is separate from the citizenry. Representatives are citizens, but they are at the same time distinct from the simple citizenry that they are commonly expected to represent. Representative democracy shifts daily political obligations and duties to individuals within this structure and legitimises this shift through some degree of oversight and control of representatives by the citizenry. Yet where two social and political groups or classes exist - one with direct political power over the other, and the other with relatively limited direct political power over itself - the relations between these two groups is determinant of democracy's sustainability. The principal question which then arises is how successfully the balance between these two groups or classes can be sustained over time. But there are also secondary questions, such as the dynamics of the evolution that occurs between classes (class mobility) and the issue of the development of these power relations (hegemony and challenge). In order to begin to answer these questions, the relation between 'citizens' and 'representatives' must first be conceptualised. Accordingly, we shall go on in this section to discuss class theory and elite theory, drawing on them as two perspectives through which to conceptualise this relation.

11 Various analytical approaches have emerged from the political science and sociology literature that can be employed to understand the citizen-representative relation. Representatives might be seen as a distinct social class, perhaps with no class consciousness, or perhaps equipped with some conception of class struggle. Such a perception of class would operate against a backdrop of Marxist class distinctions of proletariat and capitalist. These distinctions have however been refined through the posthumous continuation of Karl Marx's work. Max Weber (1905) enumerated a series of classes according to a typology going beyond the classical Marxist division, by way of a division of socio-economic distinctions. Similarly, James Burnham wrote in The Managerial Revolution (1941) on the rise of a post-industrial class of managers which gains its power not through direct ownership of the means of production, but rather through managerial involvement. More recently, radical democrats have proposed that while the concept of class might still have a role in socio-political analysis, the distinctions of class need not be determined a priori. Hence, radical democrats consider plural and variable social identities and struggles (for example, Laclau \& Mouffe 2; Tønder \& Thomassen 2-3). Class theory thus permits not only the formulation of varying conceptions of class, it also allows for the formulation of varying power relations between classes. Indeed, while Marx emphasised 'property' in a time of fastpaced industrial growth, Burnham emphasised 'influence' at a time when institutions, networks and processes had taken on greater consistence in response to the conditions 
of the industrial revolution. Hence, from Marx to Burnham, and through Weber, class can be viewed as a distinction of power, one that can perhaps be extended to the distinction between those who have direct political power (representatives) and those who do not (citizens).

Rather than viewing representatives through relations of production - co-existing with the capitalist, but nonetheless imbued with a hunger for political power rather than ownership - representatives can be viewed in a context of power rather than economics. This is a basis of the more recent 'elite theory', the idea that society is ruled by a minority, which is in a position to make strong, impacting and far-reaching decisions. Thus, elite theory distinguishes itself from class theory through its focus on political control through top-down, bureaucratic organisations, rather than on economic relations (Etzioni-Halevy 19). According to elite theory, society is dominated by political power relations between elites and non-elites, rather than through the (perhaps more explicit) class-struggle of Marx and Weber.

Elite theory stems principally from Vilfredo Pareto's The Mind and Society (1935), Gaetano Mosca's The Ruling Class (1939), and Robert Michels' Political Parties (1915). Mosca's work describes society as being stratified into, on the one hand, a large unorganized majority and, on the other hand, a minority of elites which rules the majority. Pareto's work, originally published in 1916, ${ }^{1}$ put forward a sociological assessment of elites. As such, it departed from the economic analysis, stressed notably by Marxists, to focus instead on a psychological analysis. Pareto's elite is composed of the most successful individuals in a wide range of human activity - he proposed marking people on their success and grouping those with the highest marks into the category of 'elites'. Pareto then subdivided the class of elites into those who govern and those who do not. Hence Pareto's 'governing elites' are individuals who exercise their high ability in the political sphere, while the 'non-governing elites' are individuals who exert their high ability in other, non-political spheres (such as entertainment or academia). Even though both theories are assumed to have developed independently, ${ }^{2}$ the general theory of Pareto resembles that originally developed twenty years earlier by Mosca in The Ruling Class.

Robert Michels (1915) follows from Mosca, while developing the premises of elite theory in a stricter and less ideological manner (Parry 42). In contrast to the more general attempts of Mosca and Pareto to develop a sociological and political theory supported by historical evidence, Michels sought primarily to analyse political parties, and supported his analysis with a contemporary investigation of the German Social Democratic Party. As Lipset (1962: 15-6) pointed out, Michels had been active in socialist circles for a long time, but since the Socialist party was one of the only advocates of democracy in Michels' time, the demonstration that the party itself is undemocratic proved his point well. From this, Michels elucidated the effects of organisation on democracy - he wrote that "the problem of socialism is not merely a problem in economics [...] socialism is also an administrative problem, a problem of democracy" (350).

By the 1980s, three general theories had become widely adopted by political science: the Pluralist, the Marxist and the Elitist (Domhoff 1). The idea that political power is distributed amongst government and non-government institutions (that it is 'plural') was challenged to varying extents by both Marxist class theorists and by elite theorists. Following from the ideas developed by classic elite theorists, other elite theorists have 
made similar observations of the power dynamics within society. C. Wright Mills (1956), for instance, wrote of a 'power elite', which he defined as "men whose positions enable them to transcend the ordinary environments of ordinary men and women; they are in positions to make decisions having major consequences" (Mills 73).

As can be seen, various analytical approaches have been adopted to explain political relations in society. Pareto, Mosca and Michels are often referred to by the literature as classical elite theorists. While all three theorists shared a common premise of elite rule, Geraint Parry (1969) categorises Mosca and Michels as having 'an organisational approach' and Pareto as having 'a psychological approach'. Classical elite theory introduces a novel method of analysing power relations in society. It provides an alternative tool to the primarily economic focus of Marxist class theory.

\section{Democracy in the United States and the tendency towards oligarchy}

If we focus on the particular case of the United States, we can note that while a plethora of articles and books describe the workings of contemporary democracy, very few of them fundamentally reassess its core institutional and procedural assumptions. This is perhaps particularly striking when considering the contemporary Zeitgeist in political analysis - which has variously focused on the goal of reducing establishment control of the media, of reducing the role of money in politics, or on the rise of grassroots political movements (e.g. Black Lives Matters, Occupy, Democracy Spring). It is also striking when looking at the democratic qualities of certain major contemporary political outcomes - for example, when considering that the 2016 presidential election pitted against each other two nominees holding historically-low favourability ratings (Enten), whilst still leaving little leeway for third-party candidates. Political science is, to a large extent, concerned with specific concerns: political polarisation, i.e. the shifting of opinions towards ideological extremes and the minimization of moderate opinion; party sorting, i.e. the identification of political stances with parties (Baldassarri \& Gelman; Fiorina \& Abrams); voter de-alignment, or the loss of affiliation to a political party without finding a replacement for the loss; candidate-centred politics and negative campaigning (Wattenberg). Yet, at the core of many of these lines of inquiry lies the structural relation of representation binding the citizen and the politician. Analysing democracy from this more fundamental perspective - and assessing to what degree the structure of democracy can be developed or be replaced consequently pre-empts these more established lines of inquiry and may provide more fundamental opportunity for democratisation. In order to elucidate this argument, this section will discuss the commonly cited issue of money in politics, and then assess how elite theory and class theory might pre-empt this.

18 Amongst the many varied problems cited with reference to democracy, one that has gained significant attention in recent years is the role of money, leading academics to quantify the amount of money in politics and to assess its impact on campaign success and other political outcomes. This effort stems in part from a fear that, in the words of President Barack Obama's 2012 speech at the National Democratic Convention, government may be "forever beholden to the highest bidder" (Obama). In 2011, television comedian Stephan Colbert drew national attention to the corrosive problems of campaign-funding by forming, for satirical purposes, a political action committee 
(PAC) with the motto 'Americans for a Better Tomorrow, Tomorrow'. A study conducted at the Annenberg Public Policy Center at the University of Pennsylvania found that Colbert's satirical show on Comedy Central had been more successful at increasing the public's knowledge of recent campaign finance regulations than other news media (Hardy et al.), and Colbert himself won a Peabody award for this perceived educational impact of his super-PAC. Harvard Law Professor Lawrence Lessig wrote of a 'dependence corruption' (Lessig) between politicians and private money, that hinders the ability of politicians to represent citizens. In May 2014, Lessig launched the Mayday PAC (political action committee), a crowd-funded super-PAC to funnel money to candidates committed to reforming campaign finance. The initial success of this is suggested by the $\$ 7.9$ million that the Mayday PAC raised between May $1^{\text {st }}$ and September $26^{\text {th }}$. For the 2016 election, Lawrence Lessig then ran as a candidate for the Democratic party nomination, on a platform of campaign finance and electoral reform. Similarly, non-partisan political action committees (such as Wolf PAC) advocate for a constitutional convention the aim of which would be to reduce the impact of money on elections. These high-level and high-impact attempts to bring attention to and resolve democratic problems are evidence of a public awareness of the failings of democracy and a willingness to do something about it.

The possibility that money will affect political representation is a function of the centralization of representation in contemporary democracy. As opposed to direct democracy, where representation is distributed amongst the people, modern democracy centralizes power within a group or class of political representatives. Multiple protections for stability are provided by buffering public opinion through political representatives (prominent arguments are presented in Madison). Yet, this systemic reliance on representatives creates multiple vulnerabilities affecting the validity of representation. First, there is the fact that, historically, the designation of representatives in United States democracy will introduce political parties and platforms, both of which have further implications for the functioning of democracy. Second, representatives become a choking point between the popular will and political outcomes, and, as such, centralize and concentrate the possibility of sabotaging the political process (whether through pressure exerted by lobbies or through the personal ambitions of politicians). Third, new political processes are introduced to support indirect representation - prime amongst these are elections, which are subject to further influence and, it might be noted, were considered by the ancient Greeks as oligarchic rather than democratic processes. Finally, the existence of a class or group of representatives divides society into normal-citizens and super-citizens, a phenomenon which may engender class and elite dynamics. Thus the very structure of modern democracy implies this vulnerability in the process of representation, one which lies at the core of democracy.

One extreme result of this indirect structure is that democracy might tend to oligarchy and, in this sense, might prove not to be a self-sustainable political system. The notion that democracy leads to oligarchy - sometimes called the 'Machiavellian perspective'is explicitly argued by Pareto (1935), Mosca (1939), and Michels (1915). Machiavellians asserted, by way of various justifying arguments, that democracy was partly oligarchic. For Mosca, this was evident from his extensive survey of historical societies. Those advocating the rule of the people, Mosca asserted, had invariably sought to divert the power in order to gain power for themselves. He stated that the power of the political class derives from its ability to generate cohesive strategies of ascendency over the 
masses. Since the elite are a minority, they are able to organise more rapidly, communicate more readily, and adapt more flexibly to changing situations than the larger majority. Michels argued that self-governance was necessary in order to defend society against the hegemony of capital - and yet that mass society is unable to actively self-govern without organisation, and it thus seeks organisation in elected leaders in order to make decisions and to enact them. A political class consequently forms which, according to Michels, will then invariably attempt to consolidate its own power over the non-political class. Hence, while Mosca raised the hypothesis of the individual tendencies of the elite to consolidate its power, Michels extended this to the very structure of organization in society, a conclusion explained in the phrase "who says organization, says oligarchy" (cited in Parry 42). Based on organisation and disorganisation, then, the ascendency of a political class over the masses, that is, the rule of the minority over the majority, can be argued to constitute the natural political evolution of society.

21 The application of these perspectives to modern democracy has strong implications for future studies of American society in particular and to democracy generally. Humanistic social sciences, attempting to assess democracy and develop new paths for democratisation, would benefit greatly by moving a step down the hierarchy of political analysis, in order to undertake a reassessment of the institutions and processes of representative democracy. Attempts that seek to alleviate the problems of indirect democracy, while failing to account for the dynamic of the underlying political structure may be fighting against the perhaps overwhelming tendencies of the current political system to favour oligarchic over democratic outcomes. A first step for future research in this direction might be to consider that the concentration of power within the hands of a few political representatives creates vulnerabilities in the translation of the popular will to political outcomes. If it is accepted that the shifting of direct political power away from the citizenry and towards representatives tends to a process of de-democratisation, through the competition between elites and non-elites, then the structure - not only the outcomes - of democracy needs to be reassessed in order to safeguard against this shift. Future research should assess this shift away from democracy and explore new political structures that may support alternative democratic futures for society.

\section{Conclusions}

The foundational self-definition of the United States is wedded to the concept of democracy. Its institutions consolidate it, its civil religion cherishes it, its activists aspire to it. It is the mystical and amorphous stuff upon which a large part of an entire civilization imagines itself to be anchored. Yet the gap between the concept of democracy and the governance of our societies is perhaps too large to allow for superficial fixes. If one believes that our societies are indeed anchored on the supposition of a 'true' democracy, one need only look deeper, past the obfuscating cloud of our collective imaginations, to witness growing disenchantment, alienation, distrust, and sometimes apathy. While academics often focus on these apparent ailments of democracy, it is perhaps more constructive to view these as symptoms of a vulnerable political structure, rather than as problems in and of themselves. By reexamining the core assumptions of democracy - many of which are hundreds and 
sometimes thousands of years old - in line with modern society and technology, new horizons for democracy can be envisaged, which may render the problems of our current mechanisms of governments irrelevant.

Criticisms of U.S. democracy have been as varied as its solutions. The Cold War era pitted the survival of democracy against external conditions (e.g. energy scarcity, the dependence of democracy on economic surplus, and the role of capitalism in society). The 1990s emphasized the failure of the public sector model and proposed New Public Management as a solution (Ferlie 1996). The 2000s emphasized the geopolitics of democracy, while the decade from 2010 has seen the acceleration of the current emphasis on the issue of campaign financing. Yet, as this paper has argued, these criticisms and solutions miss what is a fundamental point: the very structure of representative democracy may inhibit the ideals that this organisational structure is intended to promote. Previous attempts to 'fix' democracy largely ignore the relation between normative ideals and the actual political structure - assuming, for the most part, that the core structures of society serve ideals and that the consolidation of this structure will therefore increase the probability of desirable outcomes. As a result, it is often expected that democracy will fix itself - the solution of 'democracy' is often advocated to the problem of 'democracy'.

New technologies, and particularly the Internet with its decentralized nature, provide promising avenues for exploring other options for democracy. For example, in my research I develop the concept of Internet Democracy in which the unprecedented attributes of the Internet are applied to democracy. This allows us to envisage new forms of democracy for the digital age - for instance, the promotion of decentralization as opposed to centralization, and flat power structures as opposed to hierarchies. One possible alternative to indirect representation is a passive implementation of Internet Democracy, where online content is analysed to automatically determine societal preferences and, in turn, inform policy outcomes. Paths such as this offer the opportunity to unchain ourselves from many of the constraints faced by the ancient Athenians and the Founding Fathers. By recognizing that current forms of democracy are inherently unstable -that they are vulnerable to debasing not only policy outcomes, separating them from the popular will, but also to debasing the very idea of government of the people over time-, the importance of developing fundamentally new political systems, that consolidate popular rule (rather than tend away from it), becomes evident. More generally, by shedding new light on democratic systems - whether from social, technological, philosophical, or other developments - alternative forms of government can be created with a greater potential from the outset to truly translate societal aspirations into societal realities.

\section{BIBLIOGRAPHY}

Barabas, Jason. “Democracy's Denominator Reassessing Responsiveness with Public Opinion on the National Policy Agenda". Public Opinion Quarterly 80.2 (2016): 437-59. DOI: 10.1093/poq/nfv082 
Baldassarri, Delia, and Andrew Gelman. "Partisans without Constraint: Political Polarization and Trends in American Public Opinion". American Journal of Sociology 114.2 (2008): 408-46. DOI: 10.2139/ssrn.1010098

Burnham, James. The Managerial Revolution: What is Happening in the World. New York: Van Rees Press, 1941.

Brooks, Clem, and Simon Cheng. "Declining government confidence and policy preferences in the U.S.: Devolution, regime effects, or symbolic change?" Social Forces 79.4 (2001): 1343-75. DOI: 10.1353/sof.2001.0032

Delli Carpini, Michael X. What Americans Know about Politics and Why It Matters. New Haven: Yale UP, 1996.

Delli Carpini, Michael X. "Gen. com: Youth, civic engagement, and the new information environment”. Political Communication 17.4 (2000): 341-49. DOI: 10.1080/10584600050178942

Citrin, Jack. "Comment: The Political Relevance of Trust in Government." The American Political Science Review 68.3 (1974): 973-88. DOI: 10.2307/1959141

Dahl, Robert A. Polyarchy: Participation and Opposition. New Haven: Yale UP, 1971.

Dahl, Robert A. On Democracy. New Haven: Yale UP, 1998.

Domhoff, William G. The Power Elite and the State: How Policy is Made in America. New York: Transaction Publishers, 1990.

Enten, Harvey. “Americans' Distaste for both Trump and Clinton is Record-Breaking”. Five Thirty Eight. 5 May 2016. http://fivethirtyeight.com/features/americans-distaste-for-both-trump-andclinton-is-record-breaking/

Etzioni-Halevy, Eva. The Elite Connection: Problems and Potential of Western Democracy. Cambridge, MA: Polity Press, 1993.

Ferlie, Ewan. The New Public Management in Action. Oxford: Oxford UP, 1996.

Fiorina, Morris, and Samuel Abrams. "Political polarization in the American public". Annual Review of Political Science 11.1 (2008): 563-88. DOI: 10.1146/annurev.polisci.11.053106.153836

Foa, Roberto, and Yascha Mounk. “The Democratic Disconnect.” Journal of Democracy 27.3 (2016): 5-17. https://www.journalofdemocracy.org/articles/the-danger-of-deconsolidation-thedemocratic-disconnect/

Gallup. “Americans Trust Judicial Branch Most, Legislative Least.” Gallup. 26 Sept. 2012. https:// news.gallup.com/poll/157685/americans-trust-judicial-branch-legislative-least.aspx

Habermas, Jürgen. The Structural Transformation of The Public Sphere: An Inquiry into a Category of Bourgeois Society. Cambridge, MA: MIT Press, 1991.

Hardy, Bruce, Jeffrey Gottfried, Kenneth Winneg, and Kathleen Jamieson. “Stephen Colbert's Civics Lesson: How Colbert Super PAC Taught Viewers About Campaign Finance.” Mass Communication and Society 17.3 (2014): 329-53. DOI: 10.1080/15205436.2014.891138

Hartmann, Michael. The Sociology of Elites. London: Routledge, 2007.

Hudson, William. American Democracy in Peril: Eight challenges to America's future. Washington, DC: CQ Press, 2012.

Kornbluh, Mark. Why America Stopped Voting: The Decline of Participatory Democracy and the Emergence of Modern American Politics. New York: New York UP, 2000. 
Laclau, Ernesto, and Chantal Mouffe. Hegemony and Socialist Strategy: Towards a Radical Democratic Politics. 2nd ed. London: Verso Books, 2001.

Lessig, Lawrence. Republic, Lost: How Money Corrupts Congress-and a Plan to Stop it. New York: Twelve, 2012.

Lessig, Lawrence. Republic, Lost: Version 2.0. New York: Twelve, 2015.

Lipset, Seymour. "Introduction." In Political Parties: A Sociological Study of the Oligarchical Tendencies of Modern Democracy. Ed. R. Michels. New York: The Crowell-Collier Publishing Co., 1962. 15-39.

Madison, James “Federalist Paper, Number 10.” The Federalist Papers. Ed. Richard Beeman. New York: Penguin, 2012. 23-33.

Michels, Robert. Political Parties: A sociological Study of the Oligarchical Tendencies of Modern Democracy. Ed. Seymour Lipset. New York: The Crowell-Collier Publishing Co., 1915.

Mills, Charles Wright. The Power Elite. Oxford: Oxford UP, 1956.

Miller, Arthur. H. "Political Issues and Trust in Government: 1964-1970". The American Political Science Review 68.3 (1974): 951-72. DOI: 10.2307/1959140

Mosca, Gaetano. The Ruling Class (Elementi di Scienza Politica). Ed. Livingston, Arthur. New York: McGraw-Hill Book Company, 1939.

Obama, Barack. "Remarks by the President at the Democratic National Convention". White House Website, 6 Sept. 2012. https://obamawhitehouse.archives.gov/the-press-office/2012/09/07/ remarks-president-democratic-national-convention

Pareto, Vilfredo. The Mind and Society. Ed. Livingston, Arthur. New York: Harcourt \& Co., 2012.

Parry, Geraint. Political Elites. London: G. Allen and Unwin, 1969.

Pew Research Center. "Beyond Distrust: How Americans View Their Government” (2015). https:// www.people-press.org/2015/11/23/beyond-distrust-how-americans-view-their-government/

Rawls, John. A Theory of Justice. Cambridge: Harvard UP, 2009.

Rousseau, Jean-Jacques. The Social Contract and The First and Second Discourses. Ed. Dunn, Susan. New Haven: Yale UP, 2002.

Schumpeter, Joseph. Capitalism, Socialism and Democracy. Whitefish, MT: Kessinger Publishing, LLC, 1942.

Skocpol, Theda. Diminished Democracy: From Membership to Management in American Civic Life. Norman, OK: U. of Oklahoma P., 2013.

Tønder, Lars, \& Thomassen, Lasse. Radical Democracy: Politics between Abundance and Lack. Manchester: Manchester UP, 2005.

Wattenberg, Martin. The Rise of Candidate-centered Politics: Presidential Elections of the 1980s. Cambridge: Harvard UP, 1991.

Weber, Max. Weber: Political Writings. Ed. Lassman, Peter. Cambridge: Cambridge UP, 1994.

Wood, Donald. Post-Intellectualism and the Decline of Democracy: The Failure of Reason and Responsibility in the Twentieth Century. Westport, CT: Praeger, 1996.

Young, Iris Marion. Inclusion and Democracy. Oxford: Oxford UP, 2000. 


\section{NOTES}

1. The publication dates referenced by this article refer to the English-language publications. Pareto's The Mind and Society (Pareto, 1935) corresponds to the first publication of the English translation, whereas the work was originally published in Italian in 1916. Similarly, Robert Michels' Political Parties (Michels, 1915) was first published in 1911 as Zur Soziologie des Parteiwesens in der modernen Demokratie. Likewise, Mosca's The Ruling Class (Mosca, 1939) was first published in 1896. The chronological order of the original publications was then first Mosca (in 1896), Michels (in 1911) and lastly Pareto (in 1916).

2. Arthur Livingston, who edited the first published English translations of both Parento (1935) and Mosca (1939), notes that there is neither a dialectical nor historical connection between Mosca and Parento's theories - they originated independently from each other and with different intentions (see Arthur Livingston, note IX in Mosca 1939: xxxvi).

\section{ABSTRACTS}

The question of democracy is central to any study of the United States. Yet the shortcomings of the actual workings of the democratic process in the United States are becoming increasingly evident, as witnessed in a growing disenchantment with government, the evidence of the alienation and growing apathy of citizens, coupled with a distrust of politicians. While academics often focus on these apparent ailments of democracy, it is perhaps more constructive to view them as symptoms of a vulnerable political structure, rather than as problems in themselves. This paper proposes that a re-examination of the structure of democracy in the United States, starting out from a revision of its first principles, can provide greater opportunity for a fullyfledged enhancement of the procedures of democratisation than is possible by way of the currently dominant trend in the academic literature, which argues for the pursuit of incremental improvements in government processes. This article applies both class theory and elite theory to argue that the indirect democracy of the United States is inherently vulnerable to the distortion of the public will, and ultimately to the hegemony of political elites over ordinary citizens. It concludes that an assessment of the structure of democracy through $21^{\text {st }}$-century perspectives, informed by new technology (such as Internet Democracy), offers the potential to remedy the core vulnerabilities of modern democracy. The structural analysis that is presented here, based on the specific case of the United States, demonstrates that current approaches to democracy may be likened to the remedial patching of political systems that are fundamentally obsolete. It is argued here that the acknowledgement of this limitation provides an opportunity for the emergence of fundamentally new forms of societal governance.

La question de la démocratie est d'une importance centrale pour toute étude des Etats-Unis. Cependant, les imperfections du fonctionnement effectif du processus démocratique américain sont de plus en plus patentes, comme en atteste le désenchantement grandissant à l'égard du gouvernement, les indices d'aliénation et d'apathie chez les citoyens, corrélés à la défiance vis-àvis de la classe politique. Alors que très souvent les chercheurs mettent l'accent sur ces imperfections manifestes du processus démocratique, il serait peut-être plus constructif d'y voir les symptômes de la vulnérabilité de la structure politique, plutôt que des problèmes en euxmêmes. L'article sous-tend qu'un réexamen de la structure de la démocratie aux Etats-Unis, en 
commençant par une révision de ses principes fondateurs, offre de meilleures possibilités d'un renforcement significatif des procédures de démocratisation, comparé à la tendance actuellement dominante dans la littérature scientifique qui préconise la consolidation incrémentielle des procédures de gouvernement. L'article emprunte aussi bien à la théorie des classes qu'à la théorie des élites, démontrant que la démocratie indirecte des Etats-Unis met en évidence une vulnérabilité intrinsèque à la distorsion de la volonté publique et, en dernier ressort, un biais conduisant à l'hégémonie des élites politiques sur les citoyens ordinaires. Il en déduit qu'une évaluation de la structure de la démocratie, à l'aune des perspectives du $21^{\mathrm{e}}$ siècle et en tenant compte des innovations technologiques (notamment la démocratie par Internet), peut potentiellement remédier aux vulnérabilités de la démocratie moderne. L'analyse structurelle présentée ici, à partir du cas spécifique des Etats-Unis, démontre que les approches actuellement adoptées s'agissant de la démocratie s'apparentent au "replâtrage " de systèmes politiques qui sont fondamentalement obsolètes, alors que c'est plutôt le constat de ses limites qui permettrait de saisir l'occasion pour encourager l'émergence de formes radicalement nouvelles de gouvernance sociétale.

\section{INDEX}

Keywords: United States, politics, democracy, representation, elite theory, internet Mots-clés: États-Unis, politique, démocratie, représentation, élites, internet

\section{AUTHOR}

\section{ZACH BASTICK}

Zach Bastick is Associate member of CREA, EA 370, Paris Nanterre / Fellow, Harvard Department of Government. His research interests include American politics, democratic theory and the Internet. He seeks to develop new forms of democracy through the Internet. Contact: zach.bastick [at] gmail.com 